\title{
Auxiliary Feedwater System Risk-Based Inspection Guide for the Diablo Canyon Unit 1 Nuclear Power Plant
}

Manuscript (ompleted: August 1990)

Date Published: August 1990

Prepared by

B. l. (jore, I. V. Vo, D) (j. Harrison

Pacific Northwest !aboratory

Richland, WA 99352

\section{DISCLAIMER}

This report was prepared as an account of work sponsored by an agency of the United States Government. Neither the United States Government nor any agency thereof, nor any of their employees, makes any warranty, express or implied, or assumes any legal liability or responsiproces dise or usefulness of any information, apparatus, product, or process disclosed, or represents that its use would not infringe privately owned rights. Refermanufacin to any specific commercial product, process, or service by trade name, trademark, manufacturer, or otherwise does not necessarily constitute or imply its endorsement, recomand opinions of authors the United States Government or any agency thereof. The views United States Government or any agency theref not necessarily state or reflect those of the

\section{Prepared for \\ Division of Radiation Protection and Emergency Preparedness \\ Office of Nuclear Reactor Regulation \\ U.S. Nuclear Regulatory Commission \\ Washington, DC 20555 \\ NRC FIN L1310}

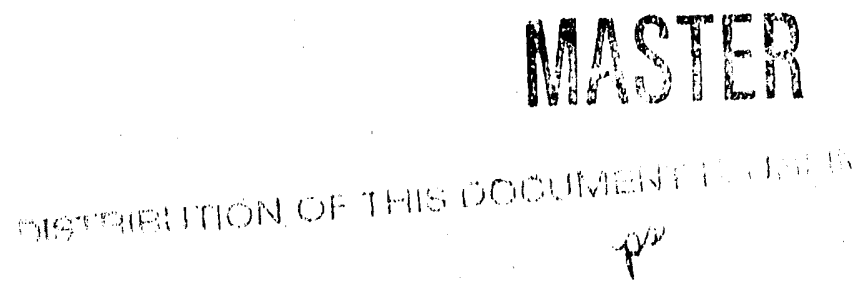


This document presents a compilation of auxiliary feedwater (AFW) system failure information which has been screened for risk significance in terms of failure frequency and degradation of system performance. It is a riskprioritized listing of failure events and their causes that are significant enough to warrant consideration in inspection planning at Diablo Canyon. This information is presented to provide inspectors with increased resourses for inspection planning at Diablo Canyon.

The risk importance of various component failure modes was identified by analys is of the results of probabilistic risk assessments (PRAs) for many pressurized water reactors (PWRs). However, the component failure categories identified in PRAs are ratiier broad, because the failure data used in the PRAs is an aggregate of many individual failures having a variety of root causes. In order to help inspectors to focus on specific aspects of component operation, maintenance and design which might cause these failures, an extensive review of component failure information was performed to identify and rank the root causes of these component failures. Both Diablo Canyon and industrywide failure information was analyzed. Failure causes were sorted on the basis of frequency of occurrence and seriousness of consequence, and catagorized as common cause failures, human errors, design problems, or component failures.

This information is presented in the body of this document. Section 3.0 provides brief descriptions of these risk-important failure causes, and Section 5.0 presents more extensive discussions, with specific examples and references. The entries in the two sections are cross-referenced.

An abbreviated system walkdown table is presented in Section 3.2 which includes only components identified as risk important. This table lists the system lineup for normal, standby system operation.

This information permits an inspector to concentrate on components important to the prevention of core damage. However, it is important to note that inspections should not focus exclusively on these components. Other components which perform essential functions, but which are not included because of high reliability or redundancy, must aiso be addressed to ensure that degredation does not increase their failure probabilities, and hence tieir risk importances. 


\section{CONTENTS}

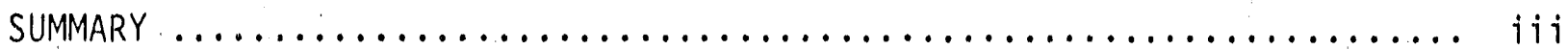

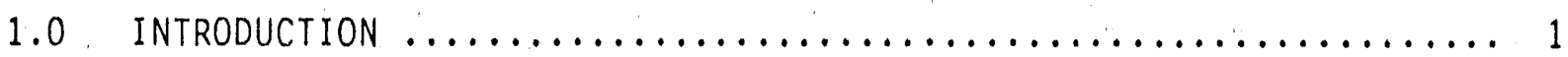

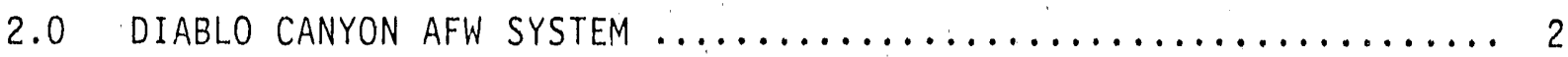

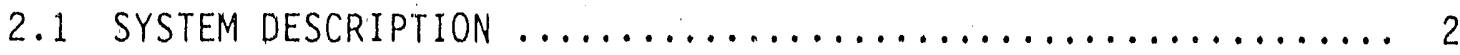

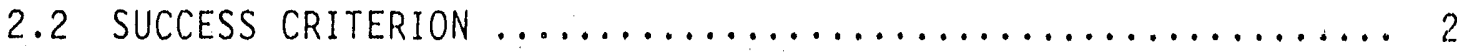

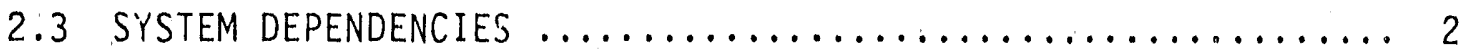

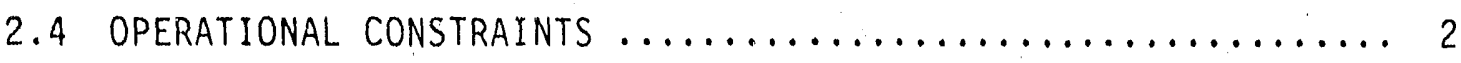

3.0 INSPECTION GUIDANCE FOR THE DIABLO CANYON AFW SYSTEM $\ldots \ldots \ldots \ldots \ldots$

3.1 RISK IMPORTANT AFW COMPONENTS AND FAILURE MODES $\ldots \ldots \ldots \ldots .5$

3.1 .1 MUTLIPLE PUMP FAILURES DUE TO COMMON CAUSE $\ldots \ldots \ldots \ldots .5$

3.1.2 TURBINE DRIVEN PUMP $1-1$ FAILS TO START OR RUN $\ldots \ldots \ldots, 6$

3.1 .3 MOTOR DRIVEN PUMP $1-2$ OR $1-3$ FAILS TO START

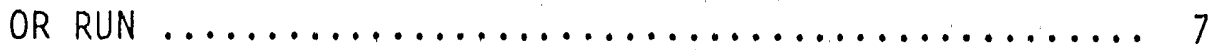

3.1.4 PUMP $1-1,1-2$ OR 1-3 UNAVAILABLE DUE TO MAINTENANCE OR SURVEILLANCE $\ldots \ldots \ldots \ldots \ldots \ldots \ldots \ldots, 7$

3.1 .5 ELECTROHYDRAULIC CONTROLLED VALVES LCV-110, 111,113, OR 115 FAIL CLOSED $\ldots \ldots \ldots \ldots \ldots \ldots \ldots \ldots, 7$

3.1.6 MOTOR OPERATED VALVES LCV-106, 107, 108, OR 109 FAIL CLOSED $\ldots \ldots \ldots \ldots \ldots \ldots \ldots \ldots \ldots, 7$

3.1 .7 MANUAL SUCTION OR DISCHARGE VALVES FAIL CLOSED $\ldots \ldots .8$

3.1 .8 LEAKAGE OF HOT FEEDWATER THROUGH CHECK VALVES ...... 9

3.2 RISK IMPORTANT AFW SYSTEM WALKDOWN TABLE $\ldots \ldots \ldots \ldots \ldots \ldots, 9$

4.0 GENERIC RISK INSIGHTS FROM PRAS $\ldots \ldots \ldots \ldots \ldots \ldots \ldots \ldots \ldots \ldots \ldots \ldots \ldots \ldots \ldots$

4.1 RISK IMPORTANT ACCIDENT SEQUENCE INYOLVING AFW SYSTEM FAILURE LOSS OF POWER SYSTEM $\ldots \ldots \ldots \ldots \ldots \ldots \ldots \ldots, 12$

4.2 RISK IMPORTANT COMPONENT FAILURE MODES $\ldots \ldots \ldots \ldots \ldots \ldots \ldots, 13$ 


\section{CONTENTS}

(Continued)

5.0 FAILURE MODES DETERMINED FROM OPERATING EXPERIENCE $\ldots \ldots \ldots \ldots \ldots, 14$

5.1 DIABLO CANYON EXPERIENCE $\ldots \ldots \ldots \ldots \ldots \ldots \ldots \ldots \ldots \ldots \ldots \ldots \ldots$

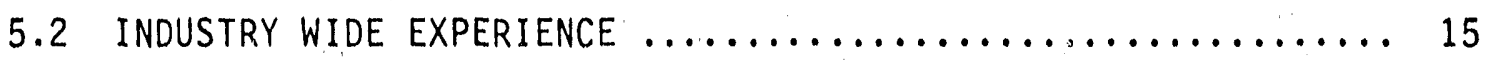

5.2 .1 COMMON CAUSE faIluRES $\ldots \ldots \ldots \ldots \ldots \ldots \ldots \ldots \ldots \ldots \ldots \ldots$

5.2 .2 HUMAN ERRORS $\ldots \ldots \ldots \ldots \ldots \ldots \ldots \ldots \ldots \ldots \ldots \ldots, 18$

5.2 .3 DESIGN/ENGINEERING PROBLEMS AND ERRORS $\ldots \ldots \ldots \ldots \ldots 18$

5.2 .4 COMPONENT FAILURES $\ldots \ldots \ldots \ldots \ldots \ldots \ldots \ldots \ldots \ldots \ldots \ldots \ldots \ldots \ldots \ldots \ldots \ldots$

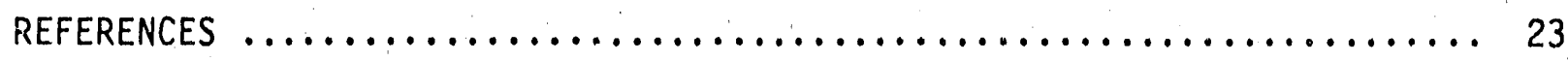




\subsection{INTRODUCTYON}

This document is the first of a series providing plant-specific inspection guidance for auxiliary feedwater (AFW) systems at pressurized water reactors (PWRS). This guidance is based on information from probabilistic risk assessments (PRAs) for similar PWRs, industry-wide operating experience with AFW systems, plant-specific. AFW system descriptions, and plant-specific operating experience. It is not a detailed inspection plan, but rather a compilation of AFW system failure information which has been screened for risk significance in terms of failure frequency and degradation of system performance. The result is a risk-prioritized listing of failure events and their causes that are significant enough to warrant consideration in inspection planning at Diablo Canyon.

This inspection guidance is presented in section 3.0, following a description of the Diablo Canyon AFW system in Section 2.0. Section 3.0 identifies the risk important sy: tem components by Diablo Canyon identification number, followed by brief descriptions of each of the various failure causes of that component. These include specific human errors, design deficiencies, and hardware failures. The discussions aiso identify where common cause failures have affected multiple, redundant components. These brief discussions identify specific aspects of system or component design, operation, maintenarice, or testing for inspection by observation, records review, training observation, procedures review, or by observation of the implementation of procedures. An AFW system walkdown table identifying risk important components and their lineup for normal, standby system operation is also provided.

The remainder of the doc ment describes and discusses the information used in compiling this inspe tion guidance. Section 4.0 describes the risk importance information which has been derived from PRAs and its sources. As review of that section will show, the failure categories identified in PRAs are rather broad (e.g., pump fails to start or run, valve fails closed). Section 5.0 addresses the specific failure causes which have been combined under these categories.

AFW system operating history was studied to identify the various specific failures which have been aggregated into the PRA failure mode categories. Section 5.1 presents a summary of Diablo Canyon failure information, and Section 5.2 presents a review of industry-wide failure information. The industrywide information was compiled from a variety of NRC sources, including AEOD analyses and reports, information notices, inspection and enforcement bulletins, and generic letters, and from a variety of INPO reports as wel1. Some Licensee Event Reports and NPRDS event descriptions were also reviewed individually. Finally, information was included from reports of NRC-sporisored studies of the effects of plant aging, which include quantitative analyses of reported AFW system failures. This industry-wide information was then combined with the plant-specific failure information to identify the various root causes of the PRA failure categories, which are identified in Section 3.0 . 


\subsection{DIABLO CANYON AFW SYSTEM}

This section presents an overview description of the Diablo Canyon AFW system, including a simplified schematic system diagram. In addition, the system success criterion, system dependencies, and administrative operational constraints are also presented.

\subsection{System Description}

The AFW system provides feedwater to the steam generators (SG) to allow secondary-side heat removal from the primary system when main feedwater is unavailable. The system is capable of functioning for extended periods, which allows time to restore main feedwater flow or to proceed with an orderly cooldown of the plant to where the residual heat removal (RHR) system can remove decay heat. A simplified schematic diagram of the AFW system is shown in Figure 2.1.

The system is designed to start up and establish flow within one minute of an automatic start signal. All pumps start on receipt of a steam generator low-low level signal. (The motor driven pumps start on low level in one $S G$, whereas, two low level signals are required for a turbine driven pump start.) The motor driven (MD) pumps start on a trip of MFW pumps or a safety injection signal and the single curbine driven (TD) pump starts on undervoltage of both $12-k V$ buses.

The normal AFW pump suction is from the condensate storage tank (CST). Each pump draws from a common header through a locked-open isolation valve and a check valve. Power, control, and instrumentation associated with each motor-driven pump are independent from one another. Steam for the turbine driven pump is supplied by steam generators 1-2 and 1-3 from a point upstream of the main steam isolation valves, through valve FCV-95. Each AFw pump is equipped with a continuous recirculation flow system, which prevents pump deadheading.

Each auxiliary feedwater pump discharge is provided with a check valve and locally operated isolation vaive. Relief valves on the suction lines to the pumps prevent main feedwater backleakage through the check valves from overpressurizing the suction lines. Each motor-driven pump normally supplies feedwater to only two steam generators, but the headers may be cross-connected. The turbine-driven pump normally supplies all four steam generators.

The CST is the normal source of water for the AFW System and is required to store sufficient demineralized water to maintain the reactor coolant system (RCS) at hot standby conditions for 8 hours with steam discharge to atmosphere. All tank connections except those required for instrumentation, auxiliary feedwater pump suction, chemical analysis, and tank drainage are located above this minimum level. AFW suction may also be switched to the raw water reservoir using the alternative suction valves.

Five additional back-up supplies of water are available. These are the condenser hotwell, the transfer tank, the fire water tank, Diablo Creek, and the Pacific Ocean. 


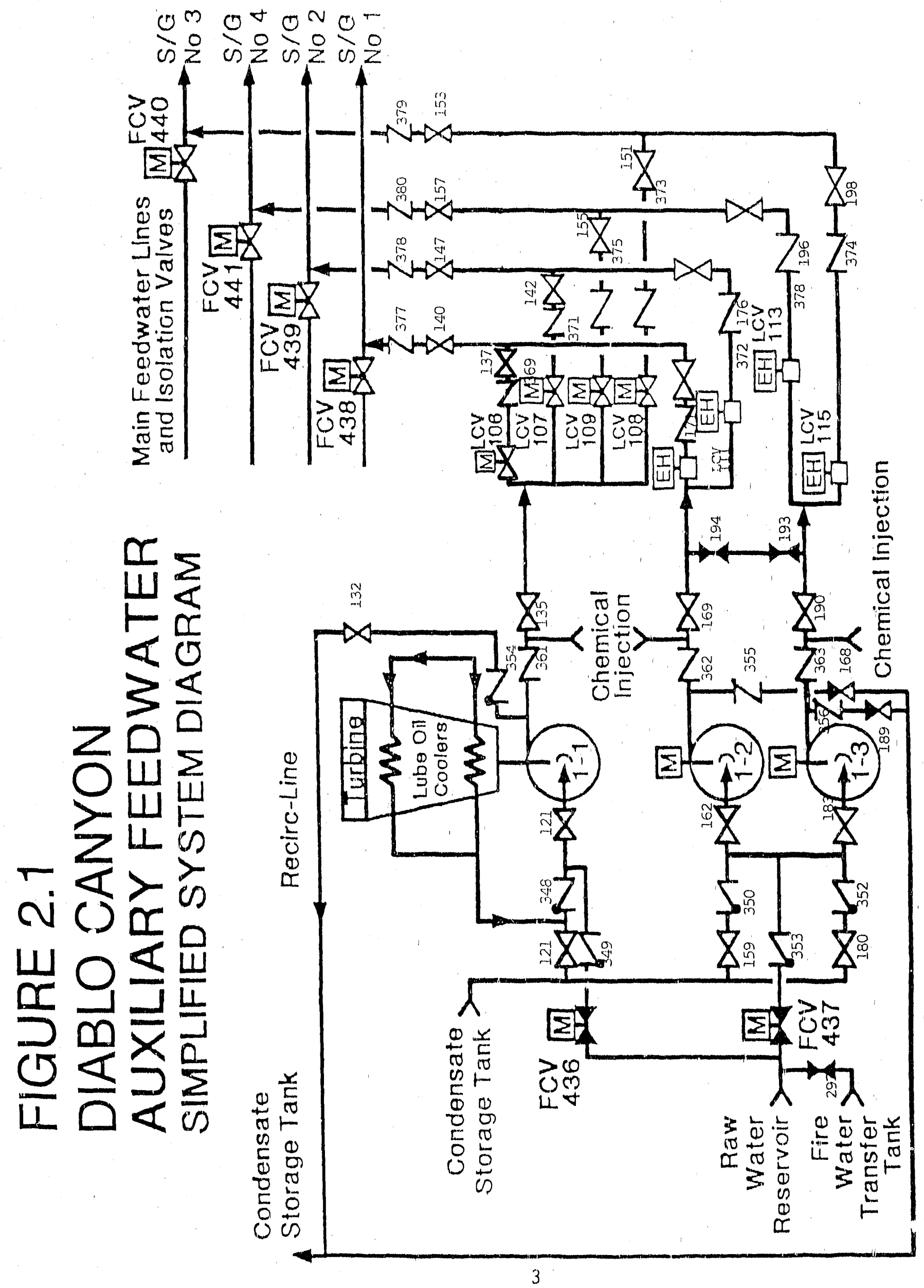




\subsection{Success Criterion}

System success requires the operation of at least one pump supplying rated flow to at least two of the four steam generators.

\subsection{System Dependencies}

The AFW system depends on AC power for motor-driven pumps and level control valves, DC power for control power to pumps and valves, and an automatic actuation signal. In addition, the turbine-driven pump also requires steam availability.

\subsection{Operational Constraints}

When the reactor is critical the Diablo Canyon Technical Specifications require that all three AFW pumps and associated flow paths are operable with each motor-driven pump powered from a different vital bus. If one AFW pump becomes inoperable, it must be restored to operable status within 72 hours or the plant must shut down to hot standby within the next six hours. If two AFW pumps are inoperable, the plant must be shut down to hot standby within six hours. With three AFW pumps inoperable, corrective action to restore at least one pump to operable status must be initiated immediately.

The Diablo Canyon Technical Specifications require an eight hour supply of water to be stored in the CST $(178,000$ gallons), with back up supplies maintained in the fire water transfer tank $(270,000$ gallons), and in the raw water reservoirs. 


\subsection{INSPECTION GUIDANCE FOR THE DIABLO CANYON AFW SYSTEM}

In this section the risk important components of the Diablo Canyon AFW system are identified, and the important modes by which they are likely to fail are briefly described. These failure modes include specific human errors, design problems, and types of hardware failures which have been observed to occur for these types of components, both at Diablo Canyon and at PWRs throughout the nuclear industry. The discussions also identify where common cause failures have affected multiple, redundant components. These brief discussions identify specific aspects of system or component design, operation, maintenance, or testing for observation, records review, training observation, procedures review or by observation of the implementation of procedures.

Table 3.1 is an abbreviated AFW system walkdown table which identifies risk important components. This table lists the system lineup for normal, standby system operation. Inspection of the components identiffed addresses essentially all of the risk associated with AFW systell operation.

\subsection{Risk Important AFW Components and Failure Modes}

Common cause failures of multiple pumps are the most risk-important failure modes of AFW systell components. These are followed in importance by single pump failures, level control valve failures, and individual check valve backleakage failures.

The following sections address each of these fallure modes, in decreasing order of importance. They present the impurtant root causes of these component failure modes which have been distilled from historical recorcls. Each item is keyed to discussions in Section 5.2 which present additional information on historical events.

\subsubsection{Multiple Pump Failures due to Common Cause}

The followiry listing summarizes the most important multiple-pump fallure modes identified in Section 5.2.1, Common Cause Failures, and each item is keyed to entries in that section..

- Incorrect operator intervention into automatic system functioning, including improper manual starting and securing of pumps, has caused failure of all pumps, including overspeed trip on startup, and inability to restart prematurely secured pumps. CC1.

- Valve mispositioning has caused failure of all pumps. Pump suction, steam supply, and instrument isolation valves have been involved. CC2.

- Steam binding has caused failure of multiple pumps. This resulted from leakaye of hot feedwater past check valves into a common discharge header, with several valves involved including a motor-operated discharge valve. (See item 7 below.) CC10. Multiple-pump steam binding has also resulted from improper valve lineups, and from running a pump deadheaded, CC3. 
- Pump control circuit deficiencies or design modification errors have caused failures of multiple pumps to auto start; spurious pump trips during operation, and failures to restart after pump shutdown. CC4. Incorrect setpoints and control circuit calibrations have also prevented proper operation of multiple pumps. CC5.

- Loss of a vital power bus has failed both the turbine-driven and one motor-driven pump due to loss of control power to steam admission valves or to turbine controls, and to motor controls powered from the same bus. CC6.

- Simultaneous startup of multiple pumps has caused oscillations of pump suction pressure causing multiple-pump trips on low suction pressure, despite the existence of adequate static net positive suction head (NPSH). CC7. Design reviews have identified inadequately sized suction piping which could have yielded insufficient NPSH to support operation of more than one pump. CC8.

\subsubsection{Turbine Driven Fump 1-1 Fails to Start or Run}

- Improperly adjusted and inadequately maintained turbine governors have caused pump faflures. HE2. Problems include worn or loosened nuts, set screws, linkages or cable connections, oil leaks and/or contamination, and electrical failures of resistors, transistors, diodes and circuit cards, and erroneous grounds and connections. CF5.

- Terry turbines with Woodward Model EG governors have been found to overspeed trip if full stearn flow is allowed on startup. Sensitivity can be reduced if a startup steam bypass valve is sequenced to open first. DE1.

- Condensate slugs in steam lines have caused turbine overspeed trip on startup. Tests repeated right after such a trip may fail to indicate the problem due to warming and clearing of the steam lines. Surveillance should exercise all steam supply connections. DE2.

- Trip and throttle valve (FCV-157) problems which have failed the turbine driven pump include physically bumping it, failure to reset it following testing, and failures to verify control room indication of reset. HEZ. Whether either the overspeed trip or TTV trip can be reset without resetting the other, indication in the control room of TTV position, and unambiguous local indication of an overspeed trip affect the likelihood of these errors. DE3.

- Turbines with Woodward Model PG-PL governors have tripped on overspeed when restarted shortly after shutdown, unless an operator has locally exercised the speed setting knob to drain oil from the governor speed setting cylinder (per procedure). Automatic oil dump valves are now available through Terry. DEA. 


\subsubsection{Motor Driven Pump 1-2 or 1-3 Fails to Start or Run}

- Control circuits used for automatic and manual pump starting are an important cause of motor driven pump fallures, as are circuit breaker fallures. CF7.

- Mispositioning of handswitches and procedural deficiencies have prevented automatic pump start. HE3.

- Low lubrication oil pressure resulting from heatup due to previous operation has prevented pump restart due to failure to satisfy the protective interlock. DE5.

\subsubsection{Pump 1-1, 1-2 or 1-3 Unavailable Due to Maintenance or Surveillance}

- Both scheduled and unscheduled maintenance remove pumps from operability. Surveillance requires operation with an altered line-up, although a pump train may not be declared inoperable during testing. Prompt scheduling and performance of maintenance and surveillance minimize this unavailability.

\subsubsection{Electrohydraulic Controlled Valves LCV-110,111, 113, or 115 Fail C'losed}

These normally-open EHVs control flow from the motor driven pumps to each of the steam generators. They fail open on loss of hydraulic pressure.

- EHV performance has been poor at other facilities, primarily due to hydraulic problems. CFG. Diablo Canyon experience has been much better.

- Leakage of hot feedwater through check valves has caused thermal binding of normally closed flow control MOVs. EHVs may be similarly susceptible. CF2.

- Multiple flow control valves have been plugged by clams when suction switched automatically to an alternate, untreated source. CC9.

\subsubsection{Motor Operated Valves LCV-106, 107, 108, or 109 Fail Closed}

These normally open MOVs control flow from the turbine driven pump to each of the steam generators. They fail as - is on loss of power.

- Common cause failure of MOVs has resulted from failure to use electrical signature tracing equipment to determine proper settings of torque switch and torque switch bypass switches. Failure to calibrate switch settings for high torques necessary under design basis accident conditions has also been involved. CC11. 
- Valve motors have been failed due to lack of, or improper sizing or use of thermal overload protective devices. Bypassing and oversizing should be based on proper engineering for destgn basis conditions. CF4.

- Out-of-adjustment electrical flow controllers have caused improper discharge valve operation, affecting multiple trains of AFW. CC12.

- Grease trapped in the torque switch spring pack of Limitorque SMB motor operators has caused motor burnout or thermal overload trip by preventing torque switch actuation. CF8.

- Manually reversing the direction of motion of operating MOVs has overloaded the motor circuit. Operating procedures should provide cautions, and circuit designs may prevent reversal before each stroke is finished. DE7.

- Space heaters designed for preoperation storage have been found wired in parallel with valve motors which had not been environmentally qualified with them present. DE7.

\subsubsection{Manual Suction or Discharge Valves Fall closed}

\begin{tabular}{l} 
TD Pump 1-1 Train: Valves $1-121,1-124$, or $1-135$ \\
MD Pump 1-2 Train: VaTves $1-159,1-162$, or $1-169$ \\
\hline MD Pump 1-3 Train: VaTves $1-180,1-183$. or $1-190$
\end{tabular}

These manual valves are normally sealed open. For each train, closure of the first valve listed would block suction from CST 1-1. Closure of the second valve would block all pump suction. Closure of the third valve would block all pump discharge except recirculation to CST $1-1$.

- Valve mispositioning has resulted in failures of multiple trains of AFW. (.C2. It has also been the dominant cause of problems identified during operational readiness inspections. HE1. Events have occurred most often during maintenance, calibration, or systern modifications. Important causes of mispositioning include:

- Failure to provide complete, clear, and specific procedures for tasks and system restoration

- Failure to promptly revise and validate procedures, training, and diagrams following system modifications

- Failure to complete all steps in a procedure

- Failure to adequately review uncompleted procedural steps after task completion

- Failure to verify support functions after restoration

- Failure to adhere scrupulously to administrative procedures regarding tagging, control and tracking of valve operations

- Failure to log the manipulation of sealed valves

- Failure to follow good practices of written task assigninent and feedback of task completion information

- Failure to provide easily read system drawings, legible valve labels corresponding to drawings and procedures, and labeled indications of local valve position 


\subsubsection{Leakage of Hot Feedwater through Check Valves:}

At MFW connections: Valves $1-377,1-378,1-379$ or $1-380$
Between Pump $1-1$ and MFW: Valves $1-369,1-371,1-373$, or $1-375$
Between Pump $1-2$ and $M F W:$ Valves $1-370$ or $1-372$
Between Pump $1-3$ and MFW: Valves $1-374$ or $1-376$
At Pump Discharges: Valves $1-361,1-362$, or $1-363$

- Leakage of hot feedwater through several check valves in series has caused steam binding of multiple pumps. Leakage through a closed level control valve in series with check valves has also occurred, as would be required for leakage to reach the motor driven pumps $1-2$ and $1-3$. CC10.

- Slow leakage past the final check valve of a series may not force upstream check valves closed, allowing leakage past each of them in turn. Piping orientation and valve design are important factors in achieving true series r rotection. CF1.

\subsection{Risk Important AFW System Walkdown Table}

Table 3.1 presents an AFW system walkdown table inciuding only components identified as risk important. This information allows inspectors to concentrate their efforts on components important to prevention of core damage. However, it is essential to note that inspections should not focus exclusively on these comments. Other components which perform essential functions, but which are absent from this table because of high reliability or redundancy, must also be addressed to ensure that their risk importances are not increased. Examples include the (open) steam lead isolation valves upstream of FCV-95, an adequate water level in the CST, and the (closed) valves cross connecting the discharges of the two motor-driven AFW pumps. 
TABLE 3.1. Risk Important AFW System Walkdown Table

\begin{tabular}{|c|c|c|c|}
\hline Component \# & Component Name & $\begin{array}{l}\text { Required } \\
\text { Position }\end{array}$ & $\begin{array}{c}\text { Actual } \\
\text { Position } \\
\end{array}$ \\
\hline \multicolumn{4}{|c|}{ Air } \\
\hline \multicolumn{4}{|c|}{ Electrical } \\
\hline $1-1$ & Turbine-Driven Pump & $\begin{array}{l}\text { Racked In! } \\
\text { Closed }\end{array}$ & \\
\hline $1-2$ & Motor-Driven Pump & $\begin{array}{l}\text { Racked In/ } \\
\text { closed }\end{array}$ & \\
\hline $1-3$ & Motor-Driven Pump & $\begin{array}{l}\text { Racked In/ } \\
\text { Closed }\end{array}$ & \\
\hline \multicolumn{4}{|c|}{ Valve } \\
\hline $1-135$ & AFW TDP 1-1 Discharge Valve & Sealed Open & \\
\hline $1-169$ & AFW MDP 1-2 Discharge Vaive & Sealed Open & \\
\hline $1-190$ & AFW MDP 1-3 Discharge Valve & Sealed Open & \\
\hline $1-121$ & AFW TDP 1-1 Suction Valve & Sealed Open & \\
\hline $1-124$ & A.FW TDP $1-1$ Suction Valve & Sealed Open & \\
\hline $1-159$ & AFW MDP $1-2$ Suction Valve & Sealed Open & \\
\hline $1-162$ & AFW MDP $1-2$ Suction Valve & Sealed Open & \\
\hline $1-180$ & AFW MDP 1-3 Suction Valve & Sealed Open & \\
\hline $1-183$ & AFW MDP 1-3 Suction Valve & Sealed Open & \\
\hline $1-L C V-106$ & $\begin{array}{l}\text { AFW TDP } 1-1 \text { to SG 1-1 Level } \\
\text { Control Valve }\end{array}$ & Open & \\
\hline $1-L C V-107$ & $\begin{array}{l}\text { AFW TDP 1-1 to SG 1-2 Level } \\
\text { Control Valve }\end{array}$ & Open & \\
\hline $1-L C V-108$ & $\begin{array}{l}\text { AFW TDP } 1-1 \text { to SG } 1-3 \text { Level } \\
\text { Control Valve }\end{array}$ & Open & \\
\hline $1-L C V-109$ & $\begin{array}{l}\text { AFW TDP } 1-1 \text { to SG 1-4 Level } \\
\text { Control Valve }\end{array}$ & Open & \\
\hline $1-L C V-110$ & $\begin{array}{l}\text { AFW MDP } 1-2 \text { to SG 1-1 Level } \\
\text { Control Valve }\end{array}$ & Open & \\
\hline
\end{tabular}


IABLE 3.1. Risk Important AFW System Walkdown Table (Continued)

\begin{tabular}{|c|c|c|}
\hline $1-L C V-111$ & $\begin{array}{l}\text { AFW MDP } 1-2 \text { to SG } 1-2 \text { Level } \\
\text { Control valve }\end{array}$ & Open \\
\hline $1-L C V-113$ & $\begin{array}{l}\text { AFW MDP } 1-3 \text { to SG 1-4 Leve } 1 \\
\text { Control Valve }\end{array}$ & Open \\
\hline $1-L C V-115$ & $\begin{array}{l}\text { AFW MDP } 1-3 \text { to } S G 1-3 \text { Level } \\
\text { Control Valve }\end{array}$ & Open \\
\hline $1-F C V-436$ & $\begin{array}{l}\text { Raw Water Storage Reservoir } \\
\text { TDP Isolation Valve }\end{array}$ & Closed \\
\hline $1-F C V-437$ & $\begin{array}{l}\text { Raw Water Storage Reservoir } \\
\text { MDP Isolation Valve }\end{array}$ & Closed \\
\hline $1-F C V-95$ & AFW TDP Steam Admission Valve & Closed \\
\hline $1-F C V-152$ & AFW TDP Throttle-Trip Valve & Open \\
\hline $1-377$ & Piping Upstream of Check Valve & Cool \\
\hline $1-378$ & Piping Upstream of Check Valve & Cool \\
\hline $1-379$ & Piping Upstream of Check Valve & Cool \\
\hline $1-380$ & Piping Upstream of Check Valve & $\mathrm{CoO}$ \\
\hline
\end{tabular}




\subsection{GENERIC RISK INSIGHTS FROM PRAS}

PRAs for 13 PWRs were analyzed to identify risk-important accident sequences involving loss of AFW, and to identify and risk-prioritize the component failure modes involved. The results of this analysis are described in this section. They are consistent with results reported by INEL and BNL (Gregg et al 1988, and Travis et al, 1988).

\subsection{Risk Important Accident Sequences Involving AFW System Failure}

\section{Loss of Power System}

- A loss of offsite power is followed by failure of AFW. Due to lack of actuating power, the PORVs cannot be opened, preventing adequate feed-and-bleed cooling, and resulting in core damage.

- A station blackout fails all AC power except Vital AC from DC invertors, and all decay heat removal systems except the turbinedriven AFW pump. AFW subsequently fails due to battery depletion or hardware failures, resulting in core damage.

- A DC bus fails, causing a trip and failure of the power conversion system. One AFW motor-driven pump is failed by the bus loss, and the turbine-driven pump fails due to loss of turbine or valve control power. AFW is subsequently lost completely due to other failures. Feed-and-bleed cooling fails because PORV control is lost, resulting in core damage.

\section{Transient-Caused Reactor or Turbine Trip}

- A transient-caused trip is followed by a loss of PCS and AFW. Feed-and-bleed cooling fails either due to failure of the operator to initiate it, or aile to hardware failures, resulting in core damage.

Loss of Main Feedwater

- A feedwater line break drains the common water source for MFW and AFW. The operators fail to provide feedwater from other sources, and fail to initiate feed-and-bleed cooling, resulting in core damage.

- A loss of main feedwater trips the plant, and AFW fails due to operator error and hardware failures. The operators fail to initiate feed-and-bleed cooling, resulting in core damage.

\section{Steam Generator Tube Rupture}

- A SGTR is followed by failure of AFW. Coolant is lost from the primary until the RWST is depleted. HPI fails since recirculation cannot be established from the ellpty sump, and cort damage results. 


\subsection{Risk Important Component Failure Modes}

The generic component fallure modes identified from PRA analyses as important to AFW system failure are listed below in decreasing order of risk importance.

1. Turbine-Driven Pump Failure to Start or Run.

2. Motor-Driven Pump Failure to Start or Run.

3. TDP or MDP Unavailable due to Test or Maintenance.

4. AFW System Valve Failures

- steam admission valves

- trip and throttle valve

- flow control valves

- pump discharge valves

- pump suction valves

- valves in testing or maintenance.

5. Supply/Suction Sources

- condensate storage tank stop valve

- hot well inventory

- suction valves.

In addition to individual hardware, circuit, or instrument failures, each of these failure modes may result from common causes and human errors. Common cause failures of AFW pumps are particularly risk important. Valve failures are somewhat less important due to the multiplicity of steam generators and connection paths. Human errors of greatest risk importance involve: failures to initiate or control system operation when required; failure to restore proper system lineup after maintenance or testing; and failure to switch to alternate sources when required. 


\subsection{FAILURE MODES DETERMINED FROM OPERATING EXPERIENCE}

This section describes the primary root causes of component fallures of the AFW system, as determined from a review of operating histories at Diablo Canyon and at other PWRs throughout the nuclear industry. Section 5.1 describes experience at Diablo Canyon. Section 5.2 summarizes information compiled from a variety of NRC sources, including AEOD analyses and reports, information notices, inspection and enforcement bulletins, and generic letters, and from a variety of INPO reports as well. Some Licensee Event Reports (LERS) and NPRDS event descriptions were also reviewed individually. Finally, information was included from reports of NRC-sponsored studies of the effects of plant aging, which include quantitative analyses of AFW system failure reports. This information was used to identify the various root causes expected for the broad PRA-based failure categories identified in Section 4.0, resulting in the inspection guidelines presented in section 3.0.

\subsection{Diablo Canyon Experience}

The AFW system at Diablo Canyon has experienced only 15 significant equipment failures since 1985. These include failures of the AFW pumps, the pump discharge level control valves to steam generators, and pump suction and discharge valves. Failure modes include electrical, instrumentation, and hardware failures, and human errors.

\section{AFW Pump Control Logic, Instrumentation and Electrical Failures}

There have been five failures of the AFW pumps to start and/or run experienced since 1985. These have resulted from failures of a pressure switch, flow transmitter, pressure gage tap root valve being open, breaker, level indicator or other pump related failures. The failure causes are mechanical wear, corrosion, or inadequate test procedures. Failure of the turbine-driven pump to achieve rated speed or discharge pressure has resulted from incorrect governor adjustment.

\section{Failure of AFW Pump Discharge Level Control Valve to Steain Generator}

There have been three failures of the pump discharge level control valves sirice 1985. These have resulted from valve control circuit failures caused by relay failure, mechanical wear, and by contact oxidation. These valves have also experienced various packing leaks, as have pump discharge check valves.

\section{AFW Valve Failures}

Since 1985 there have been only two events involving AFW valve failures. One was a MOV failure caused by failure of the overload relay to reset. The second was a manual valve failure caused by a sheared valve key. 


\section{Human Errors}

There have been five significant human errors affecting the AFW system since 1985. Personnel have inadvertently actuated the AFW pumps during testing, failed to calibrate equipment or realign equipment in the correct position following maintenance and testing, and improperly installed valve packing. Both personnel error and inadequate procedures have been involved.

Misunderstanding of operability requirements has resulted in equipment cxceeding lechnical Specifications limits.

\subsection{Industry wide Experience}

Human errors, design/engineering problems and errors, and component failures are the primary roct causes of AFW System failures identified in a review of industry wide system operating history. Common cause fallures, which disable more than one train of this operationally redundant system, are highly risk significant, and cali result from all of these causes.

This section identifies important common cause failure modes, and then provides a broader discussion of the single fallure effects of human errors, design/engtneering problems and errors, and component fallures. Paragraphs presenting details of these failure modes are coded (e.g., CC1) and crossreferenced by inspection items in Section 3.

\subsubsection{Common Cause Failures}

The dominant cause of AFw system multiple-train failures has been human error. Design/engineering errors and component failures have been less frequent, but nevertheless significarit, causes of multiple train failures.

CC1. Human error in the form of incorrect operator intervention into automatic AFW system functioning during transients resulted in the temporary loss of al1 safety-grade AFW pumps during events at Davis Besse (NUREG-1154, 1985) and Trojan (AEOD/T416, 1983). In the Davis Besse event, improper manual initiation of the steam and feedwater rupture control system (SFRCS) led to overspeed tripping of both turbine-driven AFW pumps, probably due to the introduction of condensate into the AFW turbines from the long, unheated steall supply lines. (The system had never been tested with the abnormal, crossconnected steam supply lineup which resulted.) In the Trojan event the operator incorrectly stopped both AFW pumps due to misinterpretation of MFW pump speed indication. The diesel driven pump would not restart due to a protective feature requiring complete shutdown, and the turbine-driven pump tripped on overspeed, requiring local reset of the trip and throttle valve. In cases where manual intervention is required durir' the early stages of a transient, training should emphasize that actions should be performed methodically and deliberately to guard against such errors.

CC2. Valve mispositioning has accounted for a significant fraction of the human errors failing multiple trains of AFW. This includes closure of normally open suction valves or steam supply valves, and of isolation valves to sensors having control functions. Incorrect, handswitch positioning and inadequate temporary wiring changes have also prevented automatic starts of multinlu pumps. Factors identified in studies of mispositioning errors illclude failure 
to add newly installed valves to valve checklists, weak administrative control of tagging, restoration, independent verification, and locked valve logging, and inadequate adherence to procedures. Illegible or confusing local valve labeling, and insufficient training in the determination of valve position may cause or mask mispositioning, and survelllance which does not exercise complete system functioning may not reveal mispositionings.

CC3. At ANO-2, both AFW pumps lost suction due to steam binding when they were lined up to both the CST and the hot startup/blowdown demineralizer effluent (AEOD/C404, 1984). At Zton-1 steam created by running the turbinedriven pump deadheaded for one minute caused trip of a motor-driven pump sharing the same inlet header, as well as damage to the turbine-driven pump (Region 3 Morning Report, 1/17/90). Both events were caused by procedural inadequacies.

CC4. Design/engineering errors have accounted for a smaller, but significant fraction of common cause fallures. Problems with control circuit design modifications at Farley defeated AFW pump auto-start on loss of main feedwater. At 7ion-2, restart of both motor driven pumps was blocked by circuit failure to deenergize when the pumps had been tripped with an automatic start signal present (IN 82-01, 1982). In addition, AFW control circult design reviews at Salem and Indian Point have identified designs where fallures of a single component could have failed all or multiple pumps (IN 87-34, 1987).

CC5. Incorrect setpoints and control circuit settings resulting from analysis errors and fallures to update procedures have also prevented pump start and caused pumps to trip spuriously. Errors of this type may remain undetected despite surveillance testing, unless surveillance tests model all types of system initiation and operating conditions. A greater fraction of instrumeritation and control circuit problems has been identiffed during actual system operation (as opposed to survelllance testing) than for other types of failures.

CC6. On two occasions at a foreign plant, fallure of a balance-of-plant inverter caused failure of two AFW pumps. In addition to loss of the motor driven pump whose auxiliary start relay was powered by the invertor, the turbine driven purnp tripped on overspeed because the governor valve opened, allowing full steam flow to the turbine. This illustrates the importance of assessing the effects of fallures of balance of plant equipinent which supports the operation of critical components. The instrumeit air system is another example of such a system.

CC7. Multiple AFW pump trips have occurred at Millstone-3, Cook-1, Trojan and zion-2 (IN 87-53, 1987) caused by brief, low pressure oscillations of suction pressure during pump startup. These oscillations occurred despite the availability of adequate static NPSH. Corrective actions taken include: extending the time delay associated with the low pressure trip, removing the trip, and replacing the trip with an alarm and operator action. 
CC8. Design errors discovered cluring AFW system reanalysts at the Robinson plant (IN 89-30, 1989) and at Millstone-1 resulted in the supply header from the CST being too small to provide adequate NPSH to the pumps if more than one of the three pumps were operating at rated flow condtions. This could lead to multiple pump failure due to cavitation. Subsequent reviews at Robinson identifled a loss of feedwater transient in which inadequate NPSH and flows less than design values had occurred, but which were not recognized at the time. Event analysis and equipment trending, as well as survefllance testing which duplicates service conditions as much as is practical, can help identify such design errors.

CC9: Asiatic clams caused fallure of two AFW flow control valves at Catawba2. whien low suction pressure caused by starting of a motor-driven pump caused suction source realignment to the Nuclear Service Water system. Pipes had not been rout ine.y treated to inhibit clain growth, nor regularly monitored to detect their presence, and no strainers were installed. The need for surveillance which exercises alternative system operational modes, as well as complete system functioning, is emphasized by this event. Spurious suction switchover has also occurred at Callaway and at McGuire, although no faflures resulted.

CC10. Common cause fallures have also been caused by component fallures (AEOD/C404, 1984). At Surry-2, both the turbine driven pump and one motor driven pump were declared inoperable due to steam binding caused by backleakage of hot water through multiple check valves. At Robinson-2 both motor driven pumps were found to be hot, and both motor and steam driven pumps were found to be inoperable at different times. Backleakage at Robinson-2 passed through closed motor-operated isolation valves in addition to multiple check valves. At Farley, both motor and turbine driven pump casings were found hot, although the pumps were not declared inoperable. In addition to multi-train fallures, numerous thcidents of single train failures have occurred, resulting in the designation of "Steall Binding of Auxiliary Feedwater Pumps" as Generic Issue 93. This generic issue was resolved by Generic Letter 88-03 (Miraglia, 1988), which required licensees to monitor AFW piping temperatures each shift, and to maintain procedures for recognizing stealm binding and for restoring system operability.

CC11. Common cause fallurcs have also failed motor operated valves. During the total loss of feedwater event at Davis Besse, the normally-open AFW isolation valves failed to open after they were inadvertently closed. The fallure was due to improper setting of the torque switch bypass switch, which preverits motor trip on the high torque required to unseat a closed valve. Previous problems with these valves had been addressed by increasing the torque switch trip setpoint - a fix which failed during the event due to the higher torque required due to high differential pressure across the valve. Similar common mode failures of MOVs have also occurred in other systems, resulting in issuance of Generic Letter 89-10, "Safety Related Motor-(operated Valve Testing and Surveillance (Partlow, 1089)." This generic letter requires licensees to develop and implement a program to provide for the testing, inspection and maintenance of all safety-related Movs to provide assurance that they will function when subjected to design bas is conditions. 
CC12. Other component fallures have also resulted in Ar', multi-train fallures. These include out-of-adjustment electrical flow control ers resulting in fimproper discharge valve operation, and a fallure of oll cooler cooling water supply valves to open due to silt accumulation.

\section{2 .2 Human Ërrors}

HE1. The overwhelmingly dominant cause of problems identified during a series of operational readiness evaluations of AFW systems was human performance. The majorlty of these human performance problems resulted from incomplete and incorrect procedures, particulariy with respect to valve lineup information. A study of valve mispositioning events involving human error identified failures in administrative control of tagging and logging, procedural compliance and completion of steps, verification of support systems, and inadequate procedures as important. Another study found that valve mispositioning events occurred most often during maintenance, calibration, or modification activitifs. Insufficient training in determining valve position, and in administrative requirements for controlling valve positioning were important causes, as was oral task assignment without task completion feedback.

HE2. Turbine driven pump failures have been caused by human errors in calibrating or adjusting governor speed control, poor governor maintenance, incorrect adjustment of governor valve and overspeed trip linkages, and errors associated with the trip and throttle valve. TTV-associated errors include physically bumping it, failure to restore it to the correct posttion after testing, and failures to verify control room indication of TTV position following actuation.

HE3. Motor driven pumps have been failed by human errors in mispositioning handswitches, and by procedure deficiencies.

\subsubsection{Design/Engineering Problems and Errors}

DE1. As noted above, the majurity of AFW subsystem failures, and the greatest relative system degradation, has been found to result from turbine-driven pump failures. Overspeed Lrips of Terry TM(a) turbines controlled by Woodward TM(b) governors have been a significant source of these failures (AEOD/C602, 1986). In many cases these overspefd trips have been caused by slow response of a Woodward Model EG governor on startup, at plants where full steam flow is allowed immediately. This oversensitivity has been removed by installing a startup steinl bypass valve which opens first, allowing a controlled turbire acceleration and buildup of oil pressure to control the governor valve when full stean flow is admitted.

DE2. Overspeed trips of Terry turbines have been caused by condensate in the steam supply lines. Condensate slows down the turbine, causing the governor valve to open farther, and overspeed results before the governor valve can respond, after the water slug clears. This was determined to be the cause of the loss-of-all-AFW event at Davis Besse (AE00/602, 1986), with condensation enhanced due to the long length of the cross-connected steam lines. Repeated tests following a cold-start trip may be successful due to system heat up.

(a) Terry is a registered trademark of the Terry Corporation, Windsor, CT.

(b) Woodward is a registered trademark of the Woodward Govenor Company, Rockford, IL. 
DE3. Turbino trip and throttle valve (TTV) problems are a signiflcant cause of turbine driven pump fallures (IN 84-66). In some cases lack of TTV posttion indication in the control rooll prevented recognition of a tripped TTV. In other cases it was posstble to reset efther the overspeed trip or the TTV without reseting the other. This problem is compounded by the fact that the position of the overspeed trip linkage can be misleading, and the mechanism may lack labels indicating when it is tin the tripped position (AE00/C602, 1986).

DE4. Startup of turbines, with Woodward Model PG-PL yovernors within 30 minutes of shutdown has resulted in overspeed trips when the speed setting knob was not exercised locally to drain oil from the speel setting cylinder. Speed control is based on startup with an empty cylinder. Problems have involved turbine rotation due to both procedure violations and leaking steall. Terry has marketed two types of dump valves for automatically draining the oil after shutdown (AEOD/C602, 19836).

At Calvert Cliffs, a 1987 loss-of-offsite-power event required a quick, cold startup that resulted in turbine trip due to $P G-P L$ governor stability problems. The short-teria corrective action was installation of stiffer buffer springs (IN 88-09, 1988). Surveillance had always been preceded by turbine warmup, which illustrates the importance of testing which duplicates service conditions as much as is practical.

DE5. Reduced viscosity of gear box oil heated by prior operation caused faiture of a motor driven pump to start due to insufficient lube oil pressure. Lowering the pressure switch setpoint solved the problem, which had not been detected during testing.

DE6. Waterhammer at Palisades resulted in AFW line and hanger damage at both steam gerierators. The AFW spargers are located at the normal steall generator level, and are frequently covered and uncovered during level fluctuations. Waterhammers in top-feed-ring stealm generators resulted in maln feedline rupture at Maine Yankee and feedwater pipe cracking at Indian Point-2 (IN 84$32,1984)$.

DE7. Manually reversing the direction of motion of an operating valve has resulted in MOV fallures where such loading was not considered in the design (AC00/C603, 1986). Control circuit design may prevent this, requiring stroke completion before reversal.

DE.8. At each of the units of the South Texas project, space heaters provided by the vendor for use in preinstallation storage of MOVs were found to be wired in parallel to the C'lass $1 E 125 \mathrm{~V}$ DC motors for several AFW valves (IR $50-489 / 89-11 ; 50-499 / 89-11,1989)$. The valves had been environmentally qualified, but not with the non-safety-related heaters energized.

\subsubsection{Component Failures}

Generic Issue II.E.6.1, "In Situ Testing of Valves" was divided into four sub-issues (Beckjord, 19.99), three of which relate directly to prevention of AFW system component fathre. At the request of the NRC, in-situ testing of 
check valves was addressed by the nuclear industry, resulting in the EPRI repart, "Application Guldelines for Check Valves in Nuclear Power Plants (Brooks, 1988)." This extensive report provides information on check valve applications, limttations, and inspection techntques. In-situ testing of MOVs was addressed by Generic Letter 89-10, "Safety Related Motor-operated Valve Testing and Survefllance" (Partiow, 1989) whtch requires licensees to develop and tmplement a program for testing, inspection and maintenance of all safety-related MOVs. "Thermal Overload Protection for Electric Motors on Safety-Related Motor-Operated Valves - Gerleric Issue II.E.6.1 (Rothberg, 1988)" concludes that valve motors should be thermally protected, yet in a way which emphasizes system function over protection of the operator.

CF1. The common-cause steam binding effects of check valve leakage were Tdentified tn Section 5.2.1, entry CC10. Numerous single-train events provide additional insights into this problem. In some cases leakage of hot MFW past multiple check valves in series has occurred because adequate valve-seatirig pressure was limited to the valves closest to the steam generators (AEOD/C404, 1984). At Robinson, the pump shutdown procedure was changed to delay closing the MOVs until after the check valves were seated. At Farley, additional weights were added to the back sides of the check valve disks to ensure proper seating. Check valve rework has been done at a number of plants. Different valve designs and manufacturers are involved in this problem, and recurring leakage has been experienced, even after repair and replacement.

CF2. At Roblnson, heating of motor operated valves by check valve leakage has caused thermal binding and failure of AFW discharge valves to open on demand. At Davis Besse, high differential pressure across AFW injection valves resulting from check valve leakage has prevented MOV operation (AEOD/C6O), 1986).

CF3. Gross check valve leakage at McGuire and Robinson caused

overpressurization of the AFW suction piping. At a foreign PWR it resulted in a severe waterharmmer event. At Palo Verde-2 the MFW suction piping was overpressurized by check valve leakage from the AFW system (AEOD/C404, 1984). Gross check valve leakage through tdle pumps represents a potential diversion of AFW pullp flow.

CFA. Roughily one third of AFW system fallures have been due to valve operator fallures, with about equal failures for MOVs and AOVs. Almost half of the MOV failures were due to motor or switch failures (Casada, 1989). An extensive study of MOV events (AEOD/C603, 1986) indicates continuing inoperability problems caused by: torque switch/limit switch settings, adjustments, or failures; motor burnout; improper sizing or use of thermal overload devices; premature degradation related to inadequate use of protective devices; damage due to misuse (valve throttling, valve operator hammering); mechanical problems (loosened parts, improper assembly); or the torque switch bypass circuit improperly installed or adjusted. The study concluded that current methods and procedures at many plants are not adequate to assure that MOVs will operate when needed under credible accident conditions. Specifically, a surveillance test which the valve passed might result in undetected valve inoperability due to component failure (motor burnout, operator parts failure, stell disc 
separation) or fimproper posttioning of protective devices (thermal overload, torque switch, limit switch). Generic Letter 89-10 (Partlow, 1989) has

subsequently required licensees to implement a program ensuring that MOV switch settings are maintained so that the valves will operate under design basts conditions for the life of the plant.

CF5. Component problems have caused a significant number of turbine driven pump trips (AEOD/C602, 1986). One group of events involved worn tappet nut faces, loose cable connections, loosened set screws, fmproperly latched TTVs, and improper assembly. Another involved ofl leaks due to component or seal fallures, and oil contamination due to poor maintenance activities. Governor oil' llay not bo shared with turbine lubrication ofl, resulting in the need for separate oil changes. Electrical component failures included transistor or resistor fallures due to moistire intrusion, erroneous grounds and connections, diode fallures, and a faulty circult card.

CF6. Electrohydraultc-operated discharge valves have performed very poorly, and three of the five units using them have removed them due to recurrent faflures. Failures included ofl leals, contaminated oil, ad hydraulic pump tailures.

CF7. Control circuit failures were the dominant source of motor driven AFW pump fallures (Casada, 1989). This includes the controls used for automatic. and manual starting of the pumps, as opposed to the instrumentation inputs. Most of the remaining problems were due to clrcuit breaker failures.

CF8. "Hyclraulic lockup" of Limitorque TM(c) SMB spring packs has prevented proper spring compression to actuate the MOV torque switch, due to grease trapped in the spring pack. During a survelllance at Trojan, failure of the torque switch to trip the TTV motor resulted in tripping of the thermal overload device, leaving the turbine driven pump inoperable for 40 days until the rext surveillance (AEOD/E702, 1987). Problems result from grease changes to EXXON NEBULA TM(d) EP-O grease, one of only two greases considered environmentally qualified by Limitorque. Due to lower viscosity, it slowly migrates from the gear case into the spring pack. Grease changeover at Vermont Yankee affected 40 of the older MOVs of which 32 were safety related. Grease relief kits are needed for MO' operators manufactured before 1975. At Limerick, additional grease relief was required for MOVs manufactured since 1975. MOV refurbishment programs may yteld other changeovers to EP-O grease.

CF9. For AFW systems using air operated valves, almost half of the system degradation has resulted from fallures of the valve controller circult and its instrument inputs (Casada, 1989). Failures occurred predominantly at a few units using autollatic electronic controllers for the flow control valves, with the majority of fallures due to electrical hardware. At Turkey Point-3, controller malfunction resulted from water in the Instrument Air system due to maintenance inoperability of the air dryers.

(c) Limitorque is a registered trademark of the Limitorque Corporation, Lynchburg, VA.

(d) Nebula is a registered trademark of the Exxon Corporation, Houston, TX. 
CF10. Hoi systems using diesel driven pumps, most of the faflures were due to start control and governor speed control circuitry. Half of these occurred on demand, as opposed to during testirig (Casada, 1989).

CF11. For systems using AOVs, operabllity requires the avallability of Instrument Atr, backup air, or backup nitrogen. However, NRC Maintenance Team Inspections have fdentifled inadequate testing of check valves isolating the safety-related portion of the IA systell at several utllities (Letter, Roe to Richardson). Generic Letter 88-14 (Miraglia, 1988), requires licensees to verify by test that air-operated safety-related components will perform as expected in accordance with all design-bas is events, including a loss of normal IA. 


\subsection{REFERENCES}

Beckjord, E. S. June 30, 1989. Closeout of Generic Issue II.E.6.1." In Situ Testing of Valves". Letter to V. Stello, Jr., U.S. Nuclear Regulatory Commission, Washington, DC.

Brooks, B. P. 1988. Application Guidelines for Check Valves in Nuclear Power Plants. NP-5479, Electric Power Research Institute, Palo Alto, CA.

Casada, D. A. 1989. Auxiliary Feedwater System Aging Study. Volume 1. Operating Experience and Current Monitoring Practices. NUREG/CR-5404. U.S. Nuclear Regulatory Commission, Washington, DC.

Gregg, R. E, and R. E. Wright. 1988. Appendix Review for Dominant Generic Contributors. BLB-31-88. Idaho National Engineering Laboratory, Idaho FaTls, Idaho.

Miraglia, F. J. February 17, 1988. Resolution of Generic Safety Issue 93, "Steam Binding of Auxiliary Feedwater Pumps" (Generic Letter 88-03). U.S. Nuclear Reguiatory Commission, Washington, DC.

Miraglia, F. J. August 8, 1988. Instrument Air Supply System Problems Affecting Safety-Related Equipment (Generic Letter 88-14). U.S. Nuclear Regulatory Commission, Washington, DC.

Partlow, J.G. June 28, 1989. Safety-Related Motor-Operated Valve Testing and Surveillance (Generic Letter 89-10). U.S. Nuc Tear Regulatory Commission, Washington, DC.

Rothberg, 0. June 1988. Thermal Overload Protection for Electric Motors on Safety-Related Motor-Operated Valves - Generic Issue II.E.6.1. NUREG-1296. U.S. Nuclear Regulatory Commission, Washington, DC.

Travis, R. and J. Taylor. 1989. Development of Guidance for Gereric, Functionally Oriented PRA-Based Team Inspections for BWR Plants-Identification of Risk-Important Systems, Components and Human Actions. TLR-A-3874-T6A Brookhaven National Laboratory, Upton, New York.

\section{AEOD Reports}

AEOD/C404. W. D. Lanning. July 1984. Steam Binding of Auxiliary Feedwater Pumps. U.S. Nuclear Regulatory Commission, Washington, DC.

AEOD/C602. C. Hsu. August 1986. Operational Experience Involving Turbine Overspeed Trips. U.S. Nuclear Regulatory Commission, Washington, DC.

AEOD/C'503. E. J. Brown. December 1986. A Review of Motor-Operated Valve Performance. U.S. Nuclear Regulatory Commission, Washington, DC.

AEOD/E702. E. J. Brown. March 19, 1987. MOV Failure Due to Hydraulic Lockup From Excessive Grease in Spring Pack. II.S. Nuclear Regulatory Commission, Washington, DC. 
AEOD/T416. January 22, 1983. Loss of ESF Auxiliary. Feedwater Pump Capability at Trojan on January 22, 1983. U.S. Nuclear Regulatory Commission, Washington, $\overline{\mathrm{DC}}$.

\section{Information Notices}

IN 82-01. January 22, 1982. Auxiliary Feedwater Pump Lockout Resulting from Westinghouse W-2 Switch Circuit Modification. U.S. Nuclear Regulatory Commission, Washington, DC.

IN 84-32. E. L. Jordan. April 18, 1984. Auxiliary Feedwater Sparger and Pipe Hangar Damage. U.S. Nuclear Regulatory Commission, Washington, DC.

IN 84-66. August 17, 1984. Undetected Unavailability of the Turbine-Driven Auxiliary Feedwater Train. U.S. Nuclear Regulatory Commission, Washington, DC.

IN 87-34. C. E. Rossi. July 24, 1987. Single Failures in Auxiliary Feedwater Systems. U.S. Nuclear Regulatory Commission, Washington, DC.

IN 87-53. C. E. Rossi. October 20, 1987. Auxiliary Feedwater Pump Trips Resulting from Low Suction Pressure. U.S. Nuclear Regulatory Commission, Nashington, $D C$.

IN 88-09. C. E. Rossi. March 18, 1988. Reduced Reliability of Steam-Driven Auxiliary Feedwater Pumps Caused by Instability of Woodward PG-PL Type Governors. U.S. Nuclear Regulatory Commission, Washington, DC.

IN 89-30. R. A. Azua. August 16, 1989. Robinson Unit 2 Inadequate NPSH of Auxiliary Feedwater Pumps. Also, Event Notification 16375, August 22, 1989. U.S. Nuclear Regulatory Commission, Washington, DC.

Inspection Report

IR 50-489/89-11; 50-499/89-11. May 26, 1989. South Texas Project Inspection Report. U.S. Nuclear Regulatory Commission, Washington, DC.

\section{NUREG Report}

NUREG-1154. 1985. Loss of Main and Auxiliary Feedwater Event at the Davis Besse Plant on June 9, 1985. U.S. Nuclear Regulatory Commission, Washington, DC. 


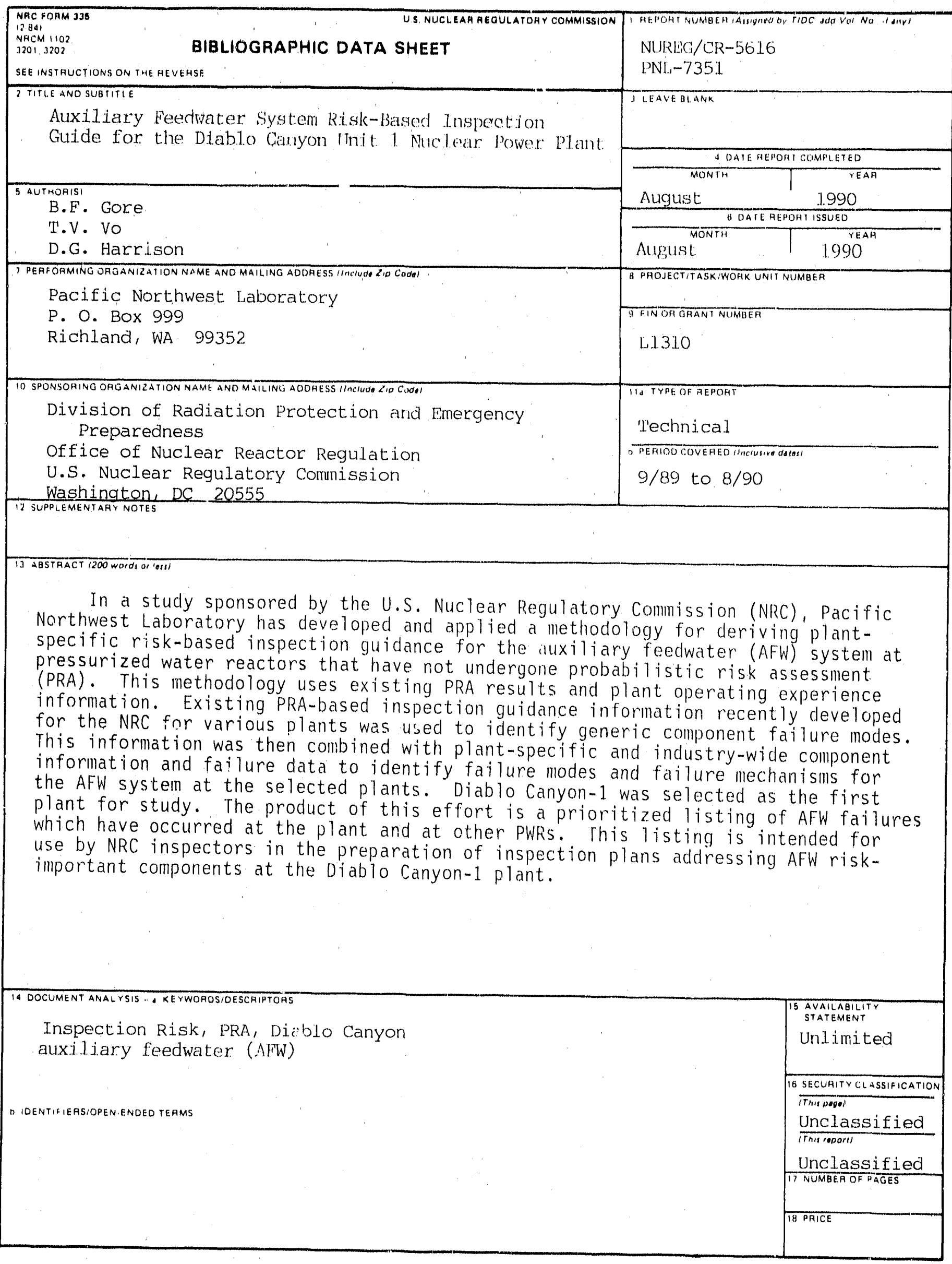



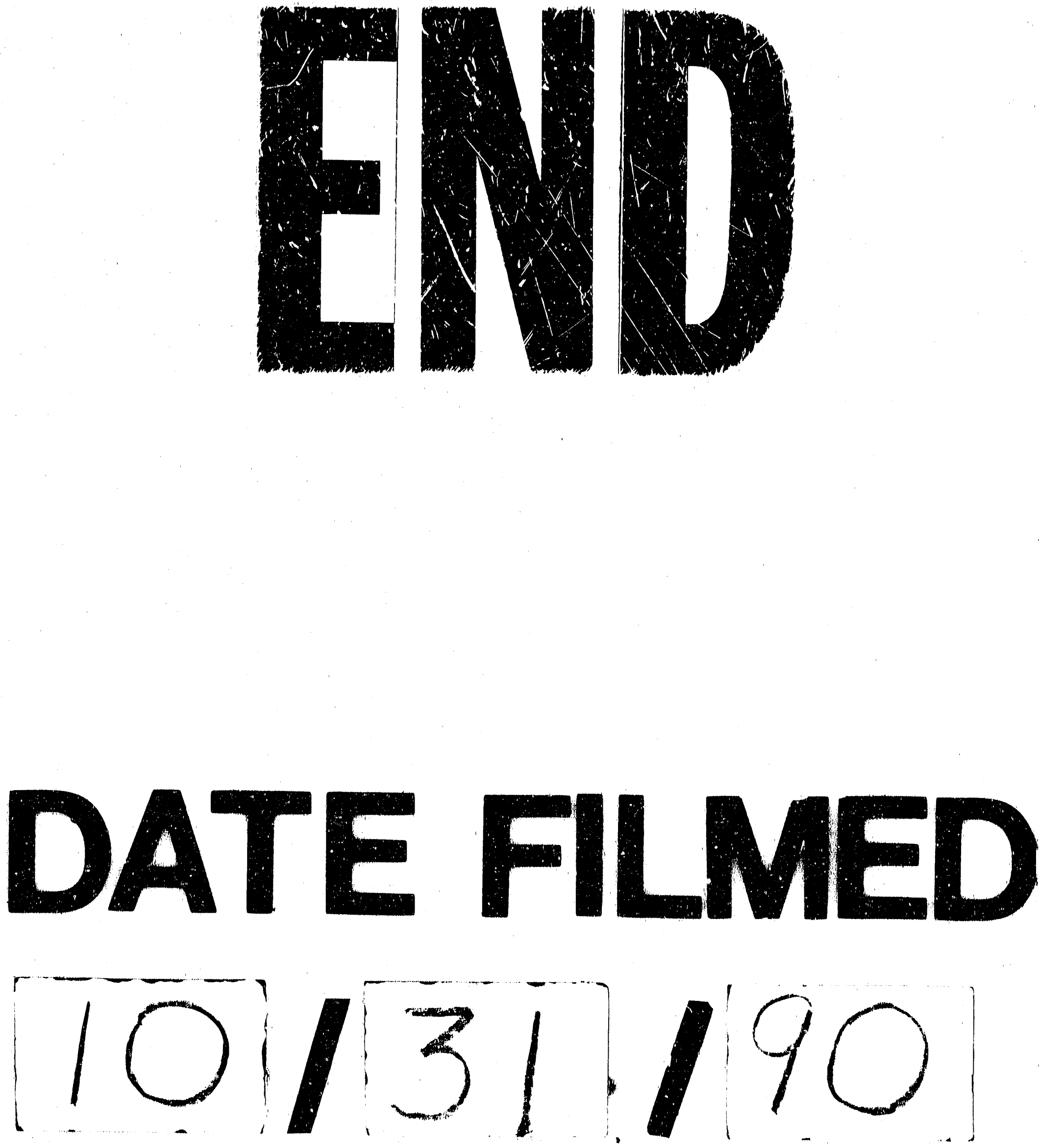
